\title{
Investigation of a Systems-Based Design and Planning Approach to a Facilities Development Project
}

\author{
S. P. Philbin \\ Imperial College London, South Kensington, London SW7 2AZ, United Kingdom \\ (s.philbin@imperial.ac.uk)
}

\begin{abstract}
This paper describes a new approach to project design and planning that has been developed at Imperial College London (UK). The management framework is based on the use of systems engineering methodologies and has been applied to the design and planning stages for a new high pressure research facility being established at Imperial College. The model includes integrated system design, systems architecture, systems integration and system-of-systems frames that are supported by the enterprise and systems theory levels. Application of the model to the case study investigation has revealed how different systems techniques can be utilized as part of an overall management approach, thereby reducing technical uncertainties in the crucial early planning stages of engineering projects.
\end{abstract}

Keywords - Systems engineering; technical project management, planning and design; facilities development and management.

\section{INTRODUCTION}

The purpose of this paper is to report on the development of a technical project design and planning framework that has been developed at Imperial College London, United Kingdom [1]. This model has been formulated to help reduce technical uncertainties, ensure project requirements are fully captured and then subsequently delivered. It was initially developed as a conceptual management framework following on from a survey of industrial organizations in the UK, which found there were a lack of available systems tools and techniques to help in the technical management of projects.

The general field of project management has developed over many years [2] and there are established processes to help practitioners (both project managers and project engineering staff), including PMBoK [3] and PRINCE2 ${ }^{\mathrm{TM}}$ [4]. These general approaches provide comprehensive frameworks to help in the management of the project lifecycle (from initiation through to delivery and eventually completion); establish project governance and organizational structures; produce project management deliverables (e.g. initiation documents, project plans and end project reports); as well as build project tools for specific processes, such as risk management and quality control. Challenges in project management do, however, remain, such as a need to improve stakeholder analysis in projects [5].

Ambiguity in project objectives and plans can reduce project performance and studies have highlighted that the deployment of structured methodologies can help enhance project decision-making [6]. Moreover, there is a need for adequate project structuring and planning at the frontend of projects [7], plus an inability to capture the full engineering requirements in 'client brief' documentation can often hamper project delivery [8]. These challenges lead to a need to improve project design and planning and this is especially relevant for highly technical and engineering projects, where there is significant complexity that if not satisfactorily managed can give rise to major uncertainties and technical risks, ultimately impacting negatively on project outcomes [9].

The field of systems engineering (SE) has, similarly to the project management subject, developed over many years [10] and the SE discipline provides engineers and managers with the methods and tools to allow engineering complexities to be tackled. It is therefore a logical progression to apply SE techniques and processes, through a holistic approach, to the aforementioned challenges in project design and planning. This application is focused on deriving the benefits from systems methodologies to achieve a reduction in technical and engineering uncertainties as well as a concomitant improvement in project design and planning.

\section{METHODOLOGY}

The project design and planning approach is based on a systems-view of projects [1]. The systems-view was formulated in response to a survey of twenty-five industrial organizations in the UK that identified a number of issues related to the management of projects from a systems engineering perspective. These findings included a continued need for traditional systems engineering approaches, such as requirements capture [11] as part of integrated system design, plus the use of systems architecting [12]. Furthermore, there were particular problems identified in the case of systems integration [13] as well as system-of-systems [14] complexities.

The management of projects was also related to the need to ensure a continued link to wider business management structures (i.e. enterprise considerations) as well as the need for adequate systems theory and knowledge. Consequently, through building on these findings as well as literature work it was possible to formulate a conceptual management tool (see Fig. 1).

The systems-view provides project engineers and management with a 'route map' to help guide the project design and planning stages but is also applicable to the resulting project delivery stage, although case study work to date has focused on design and planning. The model is based on a linear process involving progression through 
four interconnected frames that describe groups of activities to be undertaken. This backbone to the model is supported by two information levels, which are mechanisms that allow a broader consideration of issues relevant to achieving a project's objectives.

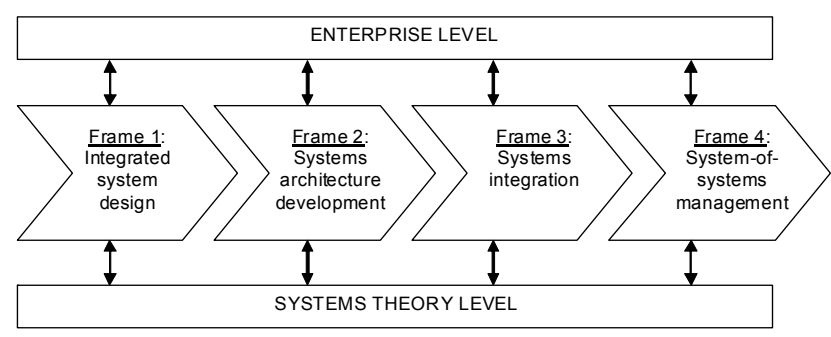

Fig. 1. Systems-view of project management [1]

The basis for applying SE to projects can be viewed in terms of the potential benefits arising from engineering systems thinking, which have been summarized in eight broad features [15]. In order to illustrate these benefits, Table I [16] provides the eight features, with the corresponding application to project management together with reference to how the systems-view model relates to each individual feature.

TABLE I [16]

\begin{tabular}{|c|c|c|}
\hline $\begin{array}{c}\text { Engineering systems } \\
\text { thinking }\end{array}$ & $\begin{array}{c}\text { Project } \\
\text { management }\end{array}$ & $\begin{array}{c}\text { Systems-view } \\
\text { model }\end{array}$ \\
\hline $\begin{array}{l}\text { Ability to see the 'big } \\
\text { picture'. }\end{array}$ & $\begin{array}{l}\text { To be able to position the } \\
\text { project within wider program } \\
\text { and business considerations. }\end{array}$ & $\begin{array}{l}\text { Enterprise level; } \\
\text { system-of-systems } \\
\text { management frame. }\end{array}$ \\
\hline $\begin{array}{l}\text { Implementation of } \\
\text { overall management } \\
\text { considerations. }\end{array}$ & $\begin{array}{l}\text { To be responsive to strategic } \\
\text { management directives, e.g. } \\
\text { achieving a certain level of } \\
\text { project performance. }\end{array}$ & Enterprise level. \\
\hline $\begin{array}{l}\text { Acquisition and use } \\
\text { of interdisciplinary } \\
\text { knowledge. }\end{array}$ & $\begin{array}{l}\text { To be comfortable managing } \\
\text { technical project elements as } \\
\text { well as other functional } \\
\text { disciplines, such as finance } \\
\text { and contracts. }\end{array}$ & $\begin{array}{l}\text { Systems theory level; } \\
\text { integrated system } \\
\text { design frame. }\end{array}$ \\
\hline $\begin{array}{l}\text { Analysis of customer } \\
\text { needs and internal } \\
\text { capabilities. }\end{array}$ & $\begin{array}{l}\text { To be able to ensure the } \\
\text { project deliverables fully } \\
\text { meet the customer needs and } \\
\text { that organizational resources } \\
\text { are fully utilised. }\end{array}$ & $\begin{array}{l}\text { Integrated system } \\
\text { design frame; systems } \\
\text { architecture } \\
\text { development frame. }\end{array}$ \\
\hline $\begin{array}{l}\text { Use of underpinning } \\
\text { systems knowledge. }\end{array}$ & $\begin{array}{l}\text { An ability to take a holistic } \\
\text { view will ensure the project } \\
\text { is benchmarked well against } \\
\text { other projects. }\end{array}$ & Systems theory level. \\
\hline $\begin{array}{l}\text { Understanding of } \\
\text { synergies and } \\
\text { emergent properties. }\end{array}$ & $\begin{array}{l}\text { An ability to manage all the } \\
\text { project streams of activity } \\
\text { could synergistically allow } \\
\text { further benefits, such as } \\
\text { repeat work or entirely new } \\
\text { project opportunities. }\end{array}$ & $\begin{array}{l}\text { Systems architecture } \\
\text { development frame; } \\
\text { systems integration } \\
\text { frame. }\end{array}$ \\
\hline $\begin{array}{l}\text { Ability to challenge } \\
\text { existing approaches. }\end{array}$ & $\begin{array}{l}\text { Challenging existing project } \\
\text { management processes, such } \\
\text { as financial control } \\
\text { mechanisms, can improve } \\
\text { project performance. }\end{array}$ & $\begin{array}{l}\text { Systems integration } \\
\text { frame; system-of- } \\
\text { systems management } \\
\text { frame. }\end{array}$ \\
\hline $\begin{array}{l}\text { Creativity and } \\
\text { creative management. }\end{array}$ & $\begin{array}{l}\text { Creatively managing project } \\
\text { staff, e.g. through providing } \\
\text { enhanced responsibilities for } \\
\text { key staff, can significantly } \\
\text { improve project } \\
\text { performance. }\end{array}$ & $\begin{array}{l}\text { Enterprise level; } \\
\text { systems theory level. }\end{array}$ \\
\hline
\end{tabular}

Table I clearly highlights a range of positive benefits that can be envisaged from the application of engineering systems thinking to project management, including the specific areas of project design and planning, which inevitably contributes significantly to a project's ultimate level of success. In order to investigate this proposition further, it is useful to apply the systems-view methodology to a case study [17], which will allow the model's attributes to be explored in more detail.

\section{CASE STUDY INVESTIGATION}

The case study involves the development of a new facilities capability at Imperial College London in the United Kingdom (the university). The author is responsible for the overall direction of the facilities project that is funded by the university. The capability is being developed in partnership with an industrial company, which is funding the procurement of specialist high pressure equipment that will be installed in the facility.

In order to establish the new facility, the university is commissioning a complex set of engineering services and supporting construction activities, which are required to allow the high-pressure equipment to be installed and operated. The project can be viewed in terms of being a 'design-bid-build' project but on a smaller scale [18]. The equipment will be used for research and teaching in the discipline of shock physics.

The project has a number of features that contribute to its complexity, namely:

- The equipment is bespoke and there is a need to optimize the specification of the equipment so that the performance parameters set by the industrial organization can be achieved.

- The development of the laboratory involving refurbishment activities, installation of new engineering services and various construction works is occurring in parallel with the equipment procurement and there is therefore a pressing need to integrate the two sets of activities.

- Whilst the equipment is being procured by the partner company, the laboratory facilities development project is being funded by the university.

- There are a large range of stakeholders for the overall initiative, including senior levels of both the university and the company. Plus, there is involvement of different academic departments as well as various administration departments from the university.

A combination of the above issues, together with a general difficulty in translating the initial customer requirements into engineering specifications for the laboratory development project can be categorized as the 'fuzzy front end' of the project [19]. Therefore, there was a particular benefit to be gained from the deployment of structured (systems) management methodologies to help 
enable the project design and planning stage and hence address this 'fuzzy' state.

\section{RESULTS}

The systems-view model was used as the overall technical management framework to guide the project design and planning activities. The model is composed of six elements (four frames and two levels) and it is useful to describe the project design and planning activities according to these six elements as part of the case study investigation. It should be noted, however, that general project management techniques, such as Gantt charts, project management and risk management plans as well as value engineering were also employed in conjunction with the technical systems methodologies.

The first frame was the integrated system design and Fig. 2 provides a summary of the overall process that was initially implemented and which is adapted from the recognized US Department of Defense (DoD) methodology [20].

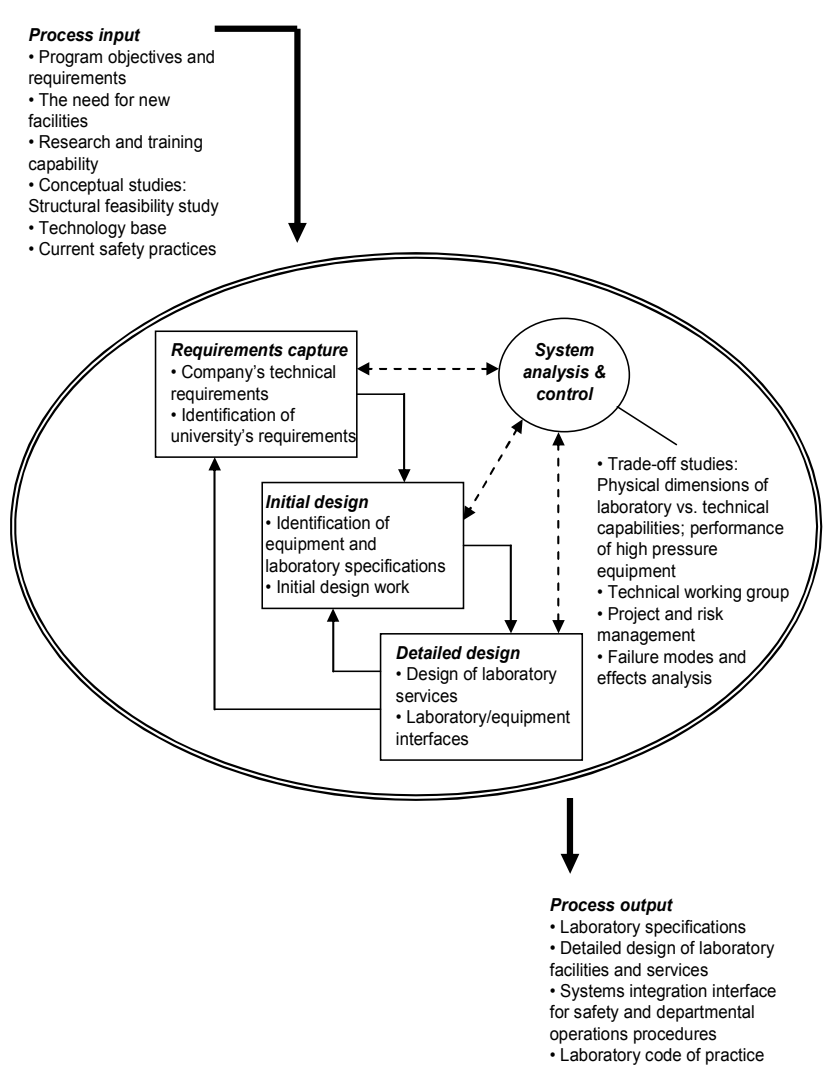

Fig. 2. Integrated system design for equipment and laboratory facility [21]

The use of the standard integrated system design approach allowed the engineering 'client brief' to be developed. This document contained the design package for the laboratory services and construction works. A crucial part of the first frame was the requirements capture process, where both the external company technical requirements had to be captured, together with internal authority requirements (e.g. health and safety, security as well as other duty holders). This joint external-internal needs gathering [22] has been shown to be an effective route to generating the functional design requirements for an engineering system, although in this case comprehensive stakeholder analysis was also undertaken [23].

Subsequent to the initial design work, there was a need to develop an enhanced safety case for the project and the FMEA (failure modes and effects analysis) method [24] was selected as a suitable tool. The FMEA process requires a system connectivity and function structure to guide the analysis process and therefore as part of the second frame of the model, a systems architecture (viewpoint-oriented structural analysis and design technique) [25] was developed (see Fig. 3). The SADT architecture was selected after a literature review [26] and because from the viewpoint of the operation of the (facility) system it is an effective system design visualization that readily highlights the main processes relevant to FMEA.

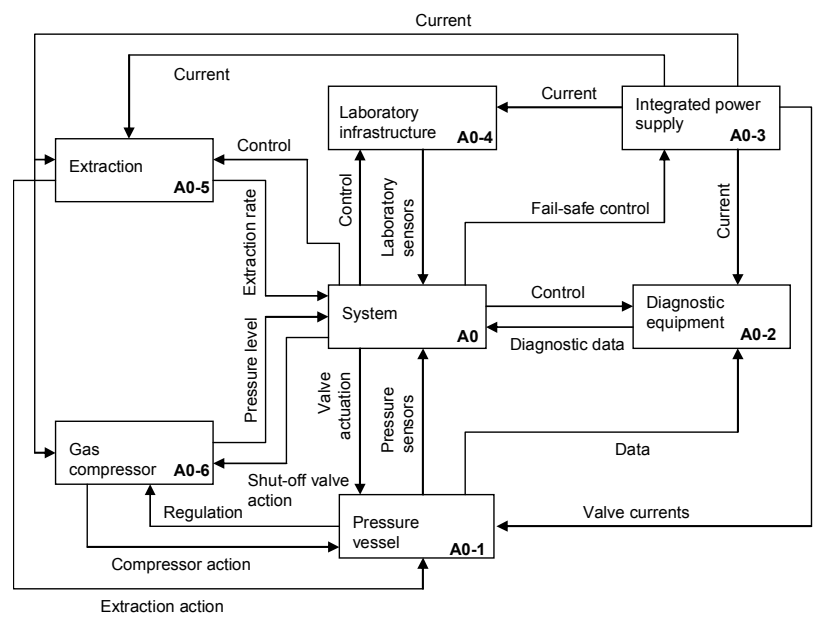

Fig. 3. Systems architecture for equipment operation [21]

Production of the systems architecture helped identify the specific failure modes for the new facility. Consequently, the mitigation measures for the most prominent and high risk failure modes could be incorporated into the facilities design.

Following on from these activities there was a need to investigate how the equipment to be procured would interface with the new laboratory infrastructure. This was especially important for the high-pressure gas subsystem. Since an inability to adequately plan this integration could result in a number of problems, such as increased safety risk; lack of dimensional connectivity between devices and apertures; inconsistent use of equipment certification and quality standards; and crucially a general lack of a systems overview on the safe and effective operation of this part of the facility. Consequently, systems integration planning (frame 3) was undertaken that involved detailed analysis (both qualitative and 
quantitative) of the integration factors that are summarized in Fig. 4.

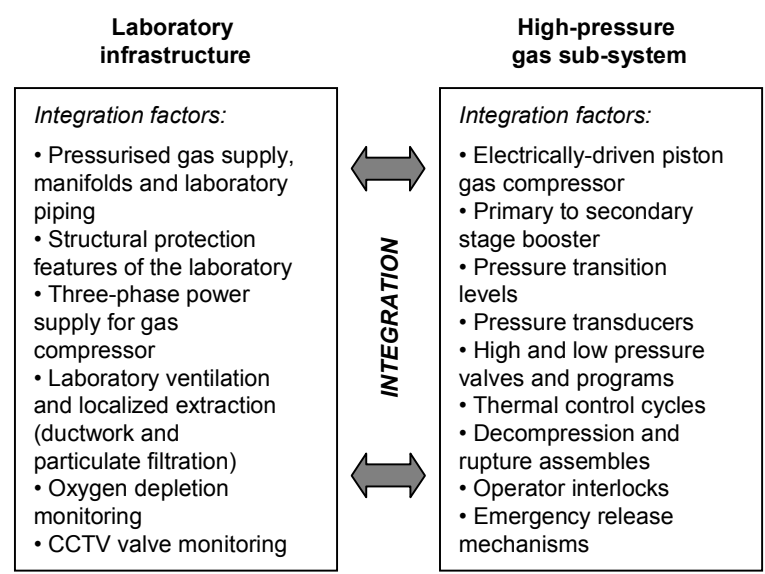

Fig. 4. Systems integration planning framework

The use of systems integration as a planning tool strengthened confidence in the overall facilities design, however, there was also a need to consider how the equipment, laboratory and operations systems would relate to other partially or non-federated systems (i.e. a system-of-systems perspective). This is because the eventual operation of the new facility would depend on both the systems within the facility as well as through an association with other systems at the university and outside the university environment. In this regard, Fig. 5 provides a system-of-systems affinity diagram [27] that was used to identify the additional areas relating to the operating conditions for the new facility before the installation works were commissioned.

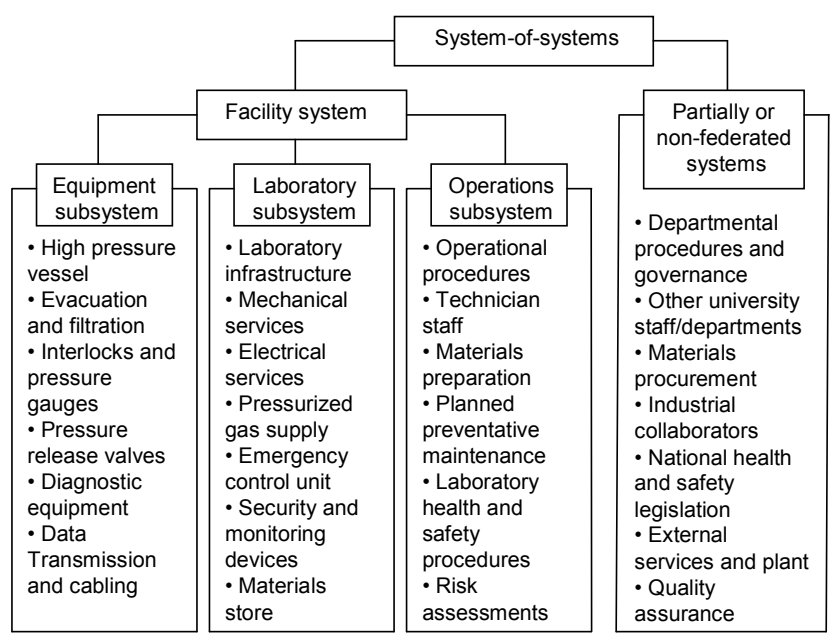

Fig. 5. System-of-systems affinity diagram

Through implementation of the systems-view model and as the project design and planning progressed there was reference to the enterprise level. This started with the initial business case for the project, which described the benefits and risks. Throughout the extended project design and planning stage (which lasted 18 months), the project's progress was reviewed by a project board and this mechanism maintained a positive association with the corporate centre of the university.

The final element of the systems-view model implementation was the systems theory level and the project required the project staff to develop improved systems and technology management skills. Especially in regard to the initial requirements capture process as well as also the need to understand how to conduct other processes, such as systems architecting. Notably, as project staff developed these improved systems skills, the implementation of the technical design activities became more streamlined and effective.

\section{DISCUSSION}

The case study investigation has highlighted how the systems-view of projects can be applied to design and planning. The systems-view has been proposed as a mechanism that is flexible and within each of the four frames and two information levels there is scope to use different systems-related tools and techniques. In this manner the model is not overly prescriptive but instead the focus is on the deployment of engineering management techniques that address increasing levels of complexity. From the initial integrated system design to systems architectures, a robust understanding of the engineering system is developed. Then, through systems integration and finally the system-of-systems frames, there is a much broader analysis of the wider system of interest (WSOI). The systems integration frame in the case study has enabled a reduction in the project's technical risks and the system-of-systems frame has allowed further planning of how the new facility will eventually operate.

Much of the project design and planning work was undertaken through a technical working group that was established early in the project. This group was chaired by the project director, with support from a project manager, technical staff from both the university and the partner company, health and safety staff as well as external engineering consultants. This multidisciplinary team was the primary channel through which the initial industrial requirements for the high-pressure experimental equipment were captured and then converted into the corresponding specifications of the laboratory to house the equipment. The use of multidisciplinary teams to drive forward such engineering initiatives has been shown to be particularly effective [28].

The performance of the team was also enhanced through gaining improved systems skills and knowledge. This was specifically required for FMEA risk management activities that involved an understanding of systems architecting techniques.

\section{CONCLUSIONS}


The systems-view of projects builds on established systems methodologies, through emphasizing the benefits of process best practice (e.g. requirements capture, systems architectures, etc.) but with a holistic perspective provided through connection to the organizational enterprise and the need for systems skills. Application of the model to a facilities development project has revealed how project design and planning can be undertaken within an overall technical framework. This approach is firmly focused on risk reduction through, for example, the systems integration planning that will help avoid any interface problems for the new facility.

Future work is suggested on the implementation of the model in the project delivery stage. A particular area for investigation will be testing and validation of the facility system against the design and planning descriptions and supporting data.

\section{ACKNOWLEDGMENT}

The author would like to thank members of the technical working group, including industrial collaborators and external engineering consultants who all contributed to the project's engineering design.

\section{REFERENCES}

[1] S. P. Philbin, "Managing Complex Technology Projects", Research-Technology Management, vol. 51, no. 2, pp. 3239, 2008.

[2] D. G. Carmichael, Project Planning and Control, Taylor and Francis, 2005.

[3] Project Management Institute (PMI), Guide to the Project Management Body of Knowledge (PMBoK), $3^{\text {rd }}$ edn., 2003.

[4] UK Office of Government Commerce (OGC), Managing Successful Projects with PRINCE2, London: TSO, 2005.

[5] A. Lund Jepsen and P. Eskerod, "Stakeholder analysis in projects: Challenges in using current guidelines in eth real world", International Journal of Project Management, vol. 27, pp. 335-343, 2009.

[6] S. Cicmil, "Understanding project management through interpretative and critical research perspectives", Project Management Journal, vol. 37, no. 2, pp. 27-37, 2006.

[7] M. Winter, "Problem structuring in project management: an application of soft systems methodology", Journal of Operational Research Society, vol. 57, issue 7, pp. 802-812, 2006.

[8] S. Wilkinson, "An analysis of the problems faced by project management companies managing construction projects", Engineering Construction and Architectural Management, vol. 8, no. 3, pp. 160-170, 2001.

[9] D. Schatteman, W. Herroelen, S. Van de Vonder and A. Boone, "Methodology for Integrated Risk Management and Proactive Scheduling of Construction Projects", Journal of Construction Engineering Management, vol. 134, issue 11, pp. 885-893, 2006.

[10] D. M. Buede, The Engineering Design of Systems: Models and Methods, John Wiley \& Sons, 1999.

[11] A. Sutcliffe, User-Centred Requirements Engineering, Springer, 2002
[12] S. V. Stephenson and A. P. Sage, "Architecting for enterprise resource planning", Information Knowledge Systems Management, vol. 6, pp. 81-121, 2007.

[13] A. Prencipe, A. Davies and M. Hobday (Eds.), The Business of Systems Integration, Oxford University Press, 2005.

[14] C. Keating, R. Rogers, R. Unal, D. Dryer, A. Souza-Poza, R. Safford, W. Peterson and G. Rabadi, "System of Systems Engineering”, Engineering Management Journal, vo. 15, issue 3, pp. 36-45, 2003.

[15] M. Frank and S. Waks, "Engineering systems thinking: A multifunctional definition", Systemic Practice and Action Research, vol. 14, no. 3, pp. 361-379, 2001.

[16] S. P. Philbin, "Bid Management: A Systems Engineering Approach", Journal of High Technology Management Research, vol. 19, issue 2, pp. 114-127, 2008.

[17] R. Pawson, Evidence-based policy: A realist perspective, London: Sage Publications, 2006.

[18] F. Y. Y. Ling, S. L. Chan, E. Chong and L. P. Ee, "Predicting Performance of Design-Build and Design-BidBuild Projects, Journal of Construction Engineering and Management, vol. 130, issue 1, pp. 75-83, 2004.

[19] P. G. Smith and D. G. Reinertsen, Developing Products in Half the Time, Van Nostrand Reinhold, 1991.

[20] Department of Defense (DoD), USA, Systems Engineering Fundamentals, Defence Acquisition University Press, 2001.

[21] S. P. Philbin, "Managing Projects Through Systems Engineering Methodologies", Proc. $29^{\text {th }}$ Conf. American Soc. for Engineering Management (ASEM), West Point, NY, pp. 1-11, 2008.

[22] M. P. Claros Salinas, G. Prudhomme and D. Brissaud, "Requirement-oriented activities in an engineering design process", International Journal of Computer Integrated Manufacturing, vol. 21, no. 2, pp. 127-138, 2007.

[23] S. Olander, "Stakeholder impact analysis in construction project management", Construction Management and Economics, vol. 25, pp. 277-287, 2007.

[24] P. C. Teoh and K. Case, "An evaluation of failure modes and effects analysis generation method for conceptual design", International Journal of Computer Integrated Manufacturing, vol. 18, no. 4, pp. 279-293, 2005.

[25] D. A. Marca, C. L. McGowan, SADT: Structural Analysis and Design Technique, McGraw-Hill, New York, NY, 1998.

[26] C. Congram and M. Epelman, "How to describe your service: An invitation to the structural analysis and design technique", International Journal of Service Management, vol. 6, issue 2, pp. 6-23, 1995.

[27] R. P. Anjard, "Management and planning tools", Training for Quality, vol. 3, issue 2, pp. 34-37, 1995.

[28] D. J. Alberts, "A model of multidiscipline teams in knowledge creating organizations", Team Performance Management, vol. 13, issue 5/6, pp. 172-183, 2007.

Dr. Simon P. Philbin holds a PhD (Brunel University) and BSc (University of Birmingham), both in chemistry as well as an MBA with distinction (Open University Business School). He is currently the Programme Director for the Institute of Shock Physics at Imperial College London (UK) and also a Visiting Fellow at Imperial College Business School. He has been with Imperial for five years and previously worked for the UK Ministry of Defence for nine years. He is a program management professional who also conducts research on systems engineering, project management and university-industrial relations. He is published in various international journals, including Research-Technology Management, European Journal of Innovation Management and Measuring Business Excellence. 